\title{
Social Responsibility And Globalization
}

\author{
Val Candy, WestCare Florida/Guidance Care Center, USA
}

\begin{abstract}
Ethics is an evaluation of moral decisions and the processes involved in making them. The term also encompasses the study of moral standards and how they apply to the social systems and organizations through which modern societies produce and distribute goods. This paper argues that moral judgments do not always transfer readily onto ethical conduct in geographically and culturally diverse nations. The existing literature tends to reject relativism in addressing how multinational organizations are guided by a core set of ethical principles regardless of the culture within which they operate. The dilemma arises when multinationals need to avoid imposing American ethical ideology and formality in localized subsidiaries.
\end{abstract}

This paper extends this dilemma to government intervention in foreign affairs and discusses how ideological positions can conflict within the same culture. This is apparent in the challenge government and private sector meet when balancing issues such as climate change with human rights. This paper supports an integrated approach toward bringing stability to influential oilproducing nations.

Keywords: Ethics; Human Rights; Climate Change; Globalization

\section{INTRODUCTION}

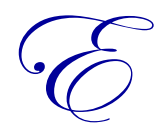

thics is the discipline that examines moral standards or the moral standards for right or wrong of a given society (Windsor, 2004). According to Shanahan and Hyman (2003), some business ethicists consider ethics to be an extension of philosophy. Philosophical approaches and principles include deontology and teleology. The deontological school of thought supports Kant's categorical imperative and the belief that behaviors are inherently right or wrong. It further supports the rights of others, the duties to others, and guides ethical actions. The teleological school of thought considers and weighs the available options and their consequences. Actions are based on the expected reward or punishment - in other words, on the extent of utility.

Ethics ask how these standards and principles apply to life and real business situations and many scholars agree that most people and businesses use both approaches to reach just and fair outcomes that minimize harm to stockholders and other stakeholders (Hunt \& Vasquez-Parraga, 1993). Measurement scales exist to assess items related to moral equity, personal or national relativism, religion, contractualism, utilitarianism, and the perceived role of ethics and social responsibility. Although Murphy (1999) did not expand his studies to broader business virtues, he proposed five core virtues for international marketing: integrity (adherence to a moral code), fairness, trust, respect for dissenting views and cultures, and empathy.

Ethics is an evaluation of moral decisions and the processes involved in making them. Business ethics is a specialized study of moral right and wrong that focuses on business institutions, organizations, and activities. The term also encompasses the study of moral standards and how they apply to the social systems and organizations through which modern societies produce and distribute goods. However, the moral judgments do not always transfer readily onto ethical conduct in geographically and culturally diverse nations. This is a real dilemma for many multinationals and care should be taken not to impose ideal American ethical practices and formalities in localized subsidiaries overseas (Fisher \& Bonn, 2007). However, the researcher literature tends to reject relativism in addressing how multinational organizations have a core set of ethical responsibilities regardless of the culture within which they operate (Donaldson, 1989). 
The focus of this paper is concerned with the social dimensions of globalization as they relate to obstacles in defining responsibilities and causation. It also outlines the link between climate change and human rights and argues that a balance is needed to maximize rights of both citizens living in vulnerable developing nations and those who are likely to lose their livelihood during the transition from traditional fossil-fuel energy sources. It is acknowledged that some scientists conclude that greenhouse gases do not present a significant threat to the planet's livability. However, the paper also supports Friedman's (2008) views that the denial is rooted in the oil industry's attempts to maintain control over future energy supplies and in its fear of the most obvious and immediate solutionmore government regulation and intervention. The consequentialist and utilitarian approach to ethics and corporate social responsibility is also discussed and concludes that neither the capitalist free-market nor socialist ideologies can defend their position in the global economy.

\section{CORPORATE SOCIAL RESPONSIBILITY}

According to Shaw (2009) the anti-capitalist views of Marx are complementary to business ethics. However, if ethical behavior is that which conforms to business norms and unethical behavior is that which violates business norms, the diverging ideological positions will vary in judgment depending upon the prevailing culture or norm (Weaver, 2011). Beyond obvious wrongdoing, such as failing to provide customers with goods purchased, misleading stockholders about an organization's financial position, or robbing the employees' pension fund, the line becomes blurred when principles are viewed from a capitalist versus socialist perspective or from the stockholder versus stakeholder perspective. This is perhaps why research tends to be descriptive rather than normative in nature (Fisher \& Bonn, 2007).

Shaw (2009) supports the view that capitalism and the pursuit of economic self-interest creates an environment where people are tempted to cut corners and to behave unethically. However, he also claims that business needs ethics, widely accepted norms, and rules to survive. Although the law can intervene where rules are broken, this cannot replace the benefits to be derived out of trusting relationships among participants. This is demonstrated through the prisoner-dilemma situation that indicates how a lack of trust (characteristic of highly capitalistic cultures) can actually reduce overall profit.

Shaw (2009) suggests that business ethics involves refining and reinforcing implicit norms within a market system that are conducive to "successful functioning". The question that remains is how to define success and for whom should the benefits be derived? Should benefits, or the resultant wealth, be distributed only to the stockholders or should they be shared with the greater society in which the business functions? Although a full discussion regarding justice and the capitalist versus socialist society is beyond the scope of this paper, the issue is in deciding what rules to apply to business and how to promote more socially responsible corporate behavior beyond legal compliance or enlightened self-interest. Reich (2007) reflects Marx's position in exclaiming that corporations need people to internalize a commitment to norms other than profit maximization and to regard themselves as having social and moral obligations beyond the financial bottom line (as cited in Shaw, 2009).

\section{CORPORATE CHARACTER}

According to Moore (2005, p. 659), corporate character is a product of modern virtue ethics and notions of "practice" and "institution". The concept of practice could be applied to business with the corporation as the "institution" which "houses" the practice; in this way, the conceptualization of a virtuous organization may be captured. The business-as-practice related concept has the potential to be a source of moral development (Moore, 2005). However, the development of ethical or corporate character depends on "internal goods" and the realization of these goods in management.

MacIntyre (1985) claimed that "internal goods" are similar to those obtained through loving relationships, playing or listening to music, or from various kinds of intellectual stimulation. In the context of business, such goods might include the enjoyment of the exercise of practical skills, the stimulation that the competitive situation affords, pride in accomplishment, and the personal dignity that derives from a job well done. By contrast, external goods are prestige, status and money. In the ideal world, different kinds of goods are mutually reinforcing, although McIntyre (1985) warns that when external goods dominate strategy, they do so at the expense (and sometimes the disappearance) of internal goods. 
When translating the internal and external goods to corporations, which are challenged to increase profit and reputation in the market, corrupt practices can replace loving ones. Ultimately, the practice of corruption will eliminate internal goods leaving the corporate character renowned for unethical behavior. Moore (2005) concludes that in a capitalist society, the quest for external goods has won over the practice - its justification is the pursuit of the goods of effectiveness. Moore claims:

... a virtuous corporate character is the seat of virtues necessary for a corporation to engage in practices with excellence, focusing on those internal goods thereby obtainable, while warding off threats form its own inordinate pursuit of external goods and form the corrupting power of other institutions with which is engages (2005, p. 661).

Koehn (1998) argues that a corporation of virtuous character needs systems and processes in place to ensure that it is not compartmentalized from other institutions in society but considers itself as one part of a whole. Further, such a corporation needs to exercise the virtues of temperance, to withstand the temptation to focus on external goods, and justice, in order to weigh its own advantage over that of the wider community. To summarize, corporate character provides the fundamental internal focus for a corporation that helps it sustain the practice at its core by maintaining equilibrium between internal and external goods.

\section{BUSINESS ETHICS AND THE STOCKHOLDER APPROACH}

The notion of corporate character and the struggle to maintain a balance between profit and other more "loving" interests might have been harshly judged by Milton Friedman (1970), who argued that the social responsibility of business is to increase its profits. According to an article that appeared in the New York Times Magazine (Friedman, 1970), in the pluralistic, capitalistic systems that have evolved in the United States, innovation and technology are grounded by the ability to earn profit in the face of the risks associated with the development of new products and services. It was Friedman (1970) who promoted the stockholder perspective to business and argued that there is no room or place in business for social conscience, providing employment, eliminating discrimination, and avoiding pollution. Borrowing a line from Voltaire's Le Tartuffe, he likens executives, who believe it is their moral responsibility to tend to such social needs, to the Frenchman who discovered - at the age of 70 - that he had been speaking prose all his life.

The stockholder perspective claims that in a free enterprise - or private-property system - a corporate executive is an employee of the owners of the business. An executive has direct responsibility to his employers. That responsibility is to conduct the business in accordance with their wishes - assumed to be to make as much profit as possible while remaining within the legal and ethical parameters that govern society. In some instances, a group of individuals might establish a corporation that is not driven by the profit motive. For example, where they elect to establish a community hospital, then the primary objective is to provide health care services to the community within which it operates and serves. Regardless of whether the corporation's purpose is to make money or provide services, the corporate executive remains an agent of those individuals who own the company. Therefore, his or her primary responsibility is to them and not to the broader society.

Svensson and Wood (2008) distinguish and compare business ethics with corporate social responsibility. They claim that although the stockholder approach does not support using company resources to benefit others at the expense of the shareholder, it does acknowledge the role that business plays in providing benefits for the good of society overall. When a business tries to maximize stockholders' profits in a free market, competition will force it to use resources more efficiently than competitors, to pay employees a competitive wage, and to provide customers with products that are better, cheaper, and safer than those of competitors. Further, Friedman (1970) did not regard profits as ends-in-themselves but rather as a vehicle to carry value items such as freedom (Cosans, 2008). The maximization of freedom defends the principle of free choice and preventing harm to others.

Friedman's (1970) critics claim that the executive's true employer is the corporation and not the stockholders. Others claim they only own stock, so their rights should be limited. Further, critics argue that it is highly improbable that the executive truly is aware of how they would want the corporation to be run. The harshest criticism of this perspective is less concerned with theory than it is application. It justifies how a company might knowingly harm society by continuing to sell its still legal product (for example, a toxic pollutant) since researching 
a less harmful one would eat into profits. However, Friedman (1970) counter-argued many of his critics by drawing parallels with unions. He claimed that the conflict of interest between profit and social responsibility (or external and internal goods) provides a more compelling argument when viewed as though union officials were asked to subordinate the interest of their members to support more general social purpose.

\section{BUSINESS ETHICS AND THE STAKEHOLDER APPROACH}

Freeman (1984) argues that an ethical evaluation of a situation is, in many cases, an exercise in stakeholder management. According to the stakeholder theory, rather than focusing on only the stockholders' interests, ethics may be evaluated by how the decision-making processes associated with products and services impact individuals and groups. Freeman (1994) did not claim that managers should not try to make a profit or even maximize profit. Rather, the claim of stakeholder theory is that the benefits should be shared among employees, consumers, communities, other interested groups, and not just the stockholder. The fundamental idea is that everyone with an interest should enjoy a share of the benefits. In turn, they will be motivated to do their part to support the corporation or business.

Freeman (1994) acknowledges two competing interpretations. The strategic interpretation claims that managing stakeholders is a means toward achieving the ends of both stockholders and the corporation's management. From this perspective, the stakeholder approach is simply viewed as good business sense as it tries to achieve its goals and objectives. The multi-fiduciary interpretation claims that executives have fiduciary obligations to stakeholders, one of which is stockholders, and that the management of stakeholder relationships is a moral requirement. According to Goodpaster (1991), this latter approach suggests that stockholders should not expect executives to discard reasonable community standards of ethics. However, stakeholder theory has drawn much positive and negative attention among business and academic circles.

Stieb (2009) argues that much of the literature misses the main points that Freeman tried to promote and also overlooks responses to his critics - many of whom support a libertarian approach to decision-making and power. His views supports the stakeholder position as a major theory (and practice) for business management given the worldwide demands for greater equity of wealth - in other words, on the grounds that it essentially calls for a redistribution of wealth by building and supporting communities where employees live and work.

Nozick (1974) persisted in claiming that there should be no central distribution controlling all the resources or how they should be shared. The libertarian approach suggests that the "price of solace and compassion is too high when it forces the redistribution of wealth from the haves to the have-nots carelessly" (Nozick, 1974, p 149). Indeed, the redistribution of wealth risks abusing those who have worked hard to earn it, although the socialist perspective would welcome its distribution based on need and ability rather than contribution. Whilst Freeman (2002) claims the concept of the stakeholder perspective is compatible with capitalism, Stieb (2009) rejects the argument that the corporation can be re-conceptualized by simply asking for whose benefit it exists. Such arguments concerning the redistribution of wealth reflect the polarization of political pillars, such as capitalism and socialism, of the greater institutional framework within which a corporation exists. As observed at the Copenhagen Climate Deal negotiations (2009), no single approach has satisfied both the contributors (developed nations) and the needy (less-developed nations) as international governments and private sector proposals fall short of achieving equity and fairness.

\section{ISSUES OF POWER, EQUITY, AND FAIRNESS}

Global climate change threatens many countries with devastation primarily due to the actions of others. However, the issue of how to distribute the costs of cutting greenhouse gas emissions has remained a stumbling block in international negotiations. Andresen and Agrawla (2002) discuss how the contentious arguments over economic justice, associated with climate change, underpin negotiations over debt relief and repayments between developed nations and international financial institutions. The entire international negotiation process raises ethical issues about moral obligations and duties to secure a sustainable future for generations to follow. 
The role of power and self-interest in international bargaining is reflected in a party's readiness to make concessions and accept a particular deal based on calculations of its relative strength compared to the other party (Snyder \& Diesing, 1977). Consequently, parties begin to secure all they can rather than their "fair" share. The outcome is a measure of the relative distribution of power, particularly in cases of asymmetry. It should not be so abusive that it removes any incentive for others to negotiate and can be used to make concessions to weaker parties over a continued state of conflict on unequal terms.

\section{UNITED NATIONS FRAMEWORK CONVENTION OF CLIMATE CHANGE (UNFCC)}

The negotiations being undertaken under the United Nations Framework Convention of Climate Change (UNFCC) are moving toward a binding agreement to limit worldwide greenhouse gas emissions. Equity considerations are implicit in all discussions surrounding distributive issues of the cost of reaching a solution, although the problem is exacerbated by the lack of consensus about the effect of different policies and mechanisms to measure allocations (Wiegandt, 2008). The divisions between developed and developing countries are obvious, but differences between the United States and the European Union, and internal opposition among strong lobbies within the U.S. also exist. The adaptations and mitigation strategies discussed within the UNFCC have differential effects on potential parties and so attention needs to be given to establishing a process of fairness and equity which would reflect the sharing of the burden among all nations while respecting the needs of future generations.

In December 2011, the UNFCC process suffered a setback when the Canadian government announced its intention to withdraw from the Kyoto Protocol Agreement. It based the decision on the grounds that the world's two largest carbon producers and emitters were failing to promote the socially responsible principles and targets of cutting emissions by 2 percent a year. This constitutes a severe blow to social responsibility and its role in securing a sustainable future - as well as its interactive effects on human rights issues. Lamentably, Canadian officials were referring to the US and to China and its response may be interpreted as a loss of faith in the rhetoric that has underpinned many international talks concerning social responsibility. Indeed, the U.S. Senate had expressed serious reservations and passed a non-binding resolution, the Byrd-Hagel Resolution, which restricted the president's negotiating position. It had resolved that any new commitment signed by the U.S. president would also have to be met by a scheduled commitment of developing countries. In addition, any agreement would have to be ratified by the Senate following a detailed explanation and review, and that no agreement would be ratified if it could harm the U.S. economy (Hohne \& Blocke, 2005).

\section{GLOBAL SOCIAL RESPONSIBILITY}

Velasquez (2009) defines corporate social responsibility as a "business's societal obligations" (p. 25). Whereas the shareholder view of Friedman claims a manager's only responsibility is to the shareholder, the stakeholder theory claims all stakeholders should have a fair share of the benefits a business produces. Business ethics is both a part of corporate social responsibility and part of the justification for corporate social responsibility. The stakeholder view (Freeman, 1994) requires the executive or manager to run the corporation in a way that balances benefits across various stakeholder groups.

Critics claim the theory fails to provide sufficient guidance and obligations upon managers to satisfy moral standards and collective responsibilities (Heath, 2006). This means the executive is left to his own moral intuition in determining whether or how to invest in better working conditions for employees or in safer products for consumers, or in reducing pollution for the local community, even if this causes a reduction in profit for the stockholder. President Obama may aspire to lead the world on climate change, but he has been seriously undermined by the failure of Congress to reach agreement on all the issues, as well as the withdrawal of corporate support. Following the Copenhagen Deal on carbon emissions, three big companies quit an influential lobbying group that had focused on shaping climate legislation. Oil giants, BP LLC, Conoco Phillips, and Caterpillar Inc. refused to renew membership to the three year old U.S. Climate Action Partnership, a broad business environmental coalition that had been instrumental in building support in Washington for capping emissions of greenhouse gases (Power \& Casselman, 2010). They based their decision on the 2011 budget calling for an array of subsidies, regulations and taxes aimed at cutting emissions. Caterpillar objected because it would impose tariffs on countries that did not match U.S. efforts to combat climate change. BP and Conoco objected because they believed the bill would not treat producers equally. 
Given the recent backlash among citizens following corporate scandals of Enron, Arthur Anderson, and WorldCom, and ever-larger mergers, such as that of J.P. Morgan, Chase, Citigroup, the consequential loss of jobs has thrust the stakeholder perspective into the limelight. As observed through the anti-capitalist protests taking place across the globe in 2011, corporations are being held accountable for the damage they have caused to society as a whole by placing consumerism and profit before social responsibility. As Svensson and Wood (2008) argue, societal institutions operate on the assumption that good will outweigh evil even though socially irresponsible managers will always exist. As globalization continues to create seamless borders where the costs of production can be greatly reduced, the socially responsible corporation will need to ensure it satisfies an increasingly sociallyconscious consumer who insists that goods purchased do not degrade the life or environment in which they are manufactured.

\section{DISTRIBUTIVE JUSTICE: CAPITALISM AND SOCIALISM}

According to Rawls' (1993) difference principle, "inequalities (or the fact that some people have more and others have less) are only justified to the extent that they favor the disadvantaged. Where this is not the case, then government should intervene to level the playing ground. Further, Rawls argues that creating value for stakeholders implies a moral obligation to put resources to work to help the less fortunate in society. Although, in a similar vein, Freeman (2002) differs to a very large extent by advocating corporate voluntary regulation over government regulation. Freeman (2002) appears to condemn the pure capitalist nature of managing by referring to the economic and legal grounds that support the need to satisfy, not only stockholders, but also employees, suppliers, and communities. Further, he claims that the stakeholder theory is compatible with societal norms and core values including fair contracts, feminism, and ecological principles (as cited in Stieb, 2009, p. 404.).

Although not a perfect fit, the notion of the stakeholder perspective seems to lend itself to a more socialist approach to the distribution of wealth. In contrast to capitalism, which dictates that wealth should be redistributed according to the level of contribution, socialism dictates that it should be redistributed based on ability and need (Velasquez, 2009). Although a full discussion comparing the two forms of government is not possible here, it is proposed that a corporation established in a highly capitalist culture (such as in the United States), would have difficulty competing in a host nation where socialist principles prevail. Governance and leadership would need to account for differences such as employment laws, which may be more favorable in the host nation, and the need to adopt a greater stakeholder perspective more commonly adopted within the industrial sector.

\section{UTILITARIAN VERSUS CATEGORICAL IMPERATIVE APPROACHES}

White and Taft (2004) claim there are two broad perspectives to analyzing ethical situations and dilemmas. The teleological school of thought views an act in relationship to its impact upon other entities. In other words, the act per se is less important than its effects. Utilitarianism, the belief that an ethical activity is one that causes the most good, or the least harm, to the greatest number of stakeholders, and egoism, the maximization of self-interest, are fundamental advocates of this perspective. Contradictory thinking includes the deontological school of thought on which Kant's categorical imperatives are based. These two broad streams of thinking are central to organizational values and cultures that, in turn, define their position within free markets across the globe. Individual ethical maturity and leadership's role in influencing ethics in businesses are also a reflection of the individuals governing and operating within them, and, according to Friedman (1970), for them.

\section{LEADERSHIP}

In light of the recent surge of ethical dilemmas in corporations across the globe, research has sought to understand the influence of leaders on ethical decision-making and behaviors throughout an organization (Brown and Trevino, 2006). There are two approaches directing research in this area. The normative perspective is philosophical in nature and addresses how people should behave in a given situation or prevailing set of circumstances. The social scientific perspective is based on the disciplines of psychology, sociology, and organizational science and examines perceptions, predispositions, and outcomes of ethical behavior, including what traits are associated with ethical leadership (Walumba \& Schaubroeck, 2009). 
Dalla Costa (1998) claims, "an ethical orientation is of substantial value because it exercises the very skills of discernment and judgment that managers need to unravel the deepening paradox of competition and success" (p. 11). Leadership (or the dark side of leadership) void of ethical consideration is not leadership at all but rather a manifestation of an insecure or narcissistic personality striving for personal, rather than socialized, power (Beerel, 2009). Where ethics may be regarded as a systematic process of reflection, application, and the challenge of norms when they may no longer be appropriate, ethical leadership needs to extend well beyond the values and norms of a given society - regardless of whether one supports ethical universalism or imperialism.

According to Sagnak (2010) research on transformational and charismatic leadership inspired interest in the field of ethics and leadership. Few would argue that ethical behavioral stems from leadership in organizations and that an organizational leader plays a critical role in developing an ethical climate. Drucker (2001) argued that the first responsibility of a professional was defined by Hippocrates thousands of years ago, and was "Primum non nocere - Above all, not knowingly to do harm" (p. 65). Surprisingly, a survey of Indian leaders revealed that integrity had disappeared from the list of the most important top ten competencies for leaders of the new economy despite the fact that it is a non-negotiable variable (Gaur, 2006).

\section{GLOBAL CAPITALISM}

Schermerhorn (1999) argues that the complexities of global capitalism place extraordinary demands on business leadership. Competitive forces and unrestricted engagement in foreign nations increase the risk of relativism and practices that would, otherwise, be unacceptable. Further, in trouble-torn difficult environments, such as Burma, businesses all too readily succumb to activist, military, or otherwise dubious expectant governments. Schermerhorn (1999) suggests that rather than being the followers of ethical decision making in such nations, that global business executives should be the leaders. For example, Levi's Robert Haus refused to do business with the Burmese government by claiming he had values and the government did not have standards.

Colin Powell (2003) commented how American companies are "ambassadors of American values - values like democracy, freedom, and respect for human dignity" (as cited in Aaronson, 2005, p. 175). However, peer leadership and peer group support is critical and Steidlmeir (1997) asks why American corporate executives are willing to lobby the U.S. government for more favorable international trade policies and practices, yet fail to join forces in lobbying to improve ethical standards in international business. Even in the green economy, used batteries in the U.S. are being shipped to Mexico where lead can be extracted using crude methods which expose workers to dangerous levels of toxic metal (Rosenthal, 2011). The Environmental Protection Agency (EPA) standards on lead protection, which make domestic recycling more difficult and expensive, do not prohibit companies from exporting to countries where standards are low and enforcement is lax. Around 20 million batteries cross the border to Mexico (legally) each year and adult workers exposed to the lead risk high blood pressure, kidney damage and abdominal pain. Exposure to children is associated with serious developmental delays and behavioral problems.

\section{RELATIVISM VERSUS UNIVERSALISM}

Rogrigues (2009) defines ethics as "basically the study of morality and standards of conduct" (p. 36). The difficulty in defining what is ethical or unethical across national boundaries stems from the notion of moral relativism which supports the case for each culture having its own set of formal and informal rules which guide behaviors - the behaviors which are considered as "normal" for a particular culture. Contrary to universalism, which advocates a single set of ethical guidelines to be honored regardless of national boundaries (such as the United Nations Global Compact Ten Principles concerning human rights, labor standards, environment, and anticorruption), relativism permits each nation to act according to its own norms which may develop over time - and through exposure to other cultures.

The ethical relativist does not believe in universal or international rights and wrongs whereas the absolutist believes in following the laws and regulations of the parent country regardless (Dowling, Festing, and Engle, 2009). Norms, values, and behaviors between cultures may frequently contradict each other and an executive may find herself or himself torn between the ethical guidelines within a host country where she or he is working as an expatriate of a parent country with an entirely different set of ethical guidelines and regulations (such as the Foreign Corrupt Practices Act of 1977) used to enforce compliance. 
The problem in defining cross-national ethics is confounded even further by the human tendency to make value-loaded judgments, as well as perceptual and cognitive biases, when trying to define what is right and what is wrong. Woodrow Wilson (1907) stated that:

Since trade ignores national boundaries and the manufacturers insist on having the world as a market, the doors of the nations which are closed to him must be battered down. Concessions obtained by financiers must be safeguarded by ministers of state, even if the sovereignty of unwilling nations be outraged in the process (as cited by Dobbin, 1998, p. 61).

Ethnocentrism, and striving to promote one cultural view as superior to the other, may inhibit the opportunities to be explored through differences and common ground. In addition, an ethnocentric approach risks giving an intolerant and arrogant impression towards others that may, in turn, damage the business relationship. A corporation or nation that subscribes to ethical universalism must apply this standard of rights and wrongs whether a decision is based on maximizing profits or on achieving other less tangible pecuniary interests. Ultimately, ethical standards are a reflection of the consumer who needs to be at the heart of strategic planning to help inform organizational policies and protocols, and the development of international attempts to reach a shared common acceptable practice.

\section{HUMAN RIGHTS}

According to Schermerhorn (1999) international business is challenged by human rights abuses and socioeconomic inequalities in poorer nations such as India and China. However, new technology and communications systems have increased the transparency of governments and multinational corporations in diverse communities as they try to conduct business ethically in complicated nations. Ironically, the employees working in grim conditions for Foxconn in Hon Hai, China could not use the new technology being assembled for high tech companies such as Sony, Apple, Hewlett-Packard, and Dell. Eventually they desperately leaked news to neighboring Hong Kong of the number of suicides, and Foxconn's response, to the oppressive working environment where people were literally jumping to their death (Dean \& Tsai, 2010).

Frost (2003) argues that the "potential for tragedy in international relations" arises when different ethical, religious, and cultural states guide behavior. The extraordinary significance of this statement is not the potential for conflict itself, but rather the negative consequences for the protagonist who meets his demise for having followed the ethical, or right, path of action.

In a pluralistic world, the absence of a core set of common values and principles threatens international relations where ethical values diverge. Systemic, corporate and personal-level ethics may be incongruent causing idealism and realism to clash. Further, egoism risks dominating the less powerful on the grounds of exercising a self-perceived superior ethical reasoning. Hence, the ethical issue is frequently one rooted in, or manifested by, the inequity of power.

\section{INTERNATIONAL RELATIONS}

Frost (2003) argues that scholars and politicians who study ethics in international relations generally seek to justify possible solutions under given circumstances. For example, whether to deploy troops to war, or whether to intervene when human rights are violated in foreign sovereignties. The demise of President Mubarak of Egypt in 2011 was one which drew the American government into its own struggle between political and ethical will as Hilary Clinton favored action to avoid what she foresaw to be a "second Rwanda", and her military counter-part argued that the cost, and possible consequences, of taking action should not be absorbed by the American taxpayer. Clearly, even within a single culture, the potential for tragedy is high and U.S. action might well have turned into a tragedy had the outcome been less acceptable to the other key international players or actors. In this instance, it seems the means justified the ends (in the short term), although tragedy is more concerned with consequentialist thinking in which the original action would have been regarded as a painful side-effect of taking the right or moral action. This is in contrast to the utilitarian approach that would have deemed the original decision to intervene as a costly mistake had it not succeeded in its mission. The variables applied to the decision making process are 
unknown but language and semantics reported in the media included debates concerning the protection of rights, justice, liberty, and democracy - all of which are fundamental ethical concerns.

The above example of potential tragedy clearly defines conflict of values; however, in many instances, the outcomes of ethical action are long-term and difficult to measure or defend when short-term gains are visible on the horizon. In this respect, even well intentioned people acting ethically might cause harm to those to whom they feel a responsibility - a term referred to as an agon (Frost, 2003). Examples include the affects of U.S action in elevating the war in Somalia, and this eventually saw the U.S indirectly supplying arms weapons to child soldiers, or how the U.S support of Israel may be regarded as antagonistic by neighboring Palestinians - in turn perpetuating the conflict of attrition. Tragedies also occur as a result of supplying human aid - United Nations safe havens in Bosnia became traps for the very people they sought to protect, and clothing sent to relieve the famine in Ethiopia served to make the few haberdashers who could still make a living redundant.

\section{MORAL DEVELOPMENT}

According to Fisher and Bonn (2007) the development of conceptual models and applications are critical to managing across borders where challenges are presented through legal, political, economic, and cultural pillars. They suggested a model based on Kohlberg's framework of moral reasoning and cognitive development. Although academics continue to debate and question the framework, the plethora of research supports a general developmental trend in moral development (Rest, 1986). Further, although Kohlberg's (1976) work was based on individual cognitive development, researchers (Trevino \& Nelson, 2004) have identified how organizational operations reflect these levels - of course, that is not to imply that organizations have a will of their own but rather that the organizational behavior of individuals collectively map onto Kohlberg's (1976) framework.

Kohlberg (1976) identified six stages in the development of an individual's ability to deal with moral issues, and these can be grouped into three levels, each containing two stages (as cited in Fisher \& Bonn, 2007). Level One is the pre-conventional stage of moral reasoning and may be characterized by obedience to law to guide activities and to avoid punishment. Falkenberg (2004) refers to this as the group egoism stage and ethics is regarded as a constraint to operations. Decision-making is based on whatever maximizes its long-term self-interest. Level Two is the conventional stage that takes into account stakeholder and society's views. Ethical behavior is seen as fulfilling societal obligations, although these may not be fully known in international business affairs. Individuals in stage two are living up to the expectations of people towards whom they feel a sense of loyalty. In addition, they acknowledge and follow the norms of society at large. Level Three is the post-conventional stage characterized by the social contract orientation, and the universal moral principles orientation. At this stage, an organization identifies universal values, principles, and rights and follows them regardless of the majority opinion. Ethics become an integral part of organizational activity. However, rather than overlooking cultural differences, care is taken to ensure international business activities are beneficial and sustainable in the long-term.

\section{RELATIVISM AND UNIVERSALISM}

Although the claim that the later stages of moral development are superior to the earlier stages in terms of a broader perspective, differing cultures and value systems make that an erroneous assumption (French, \& Weis, 2000). This is particularly pertinent to any debate concerning the acceptance of universal ethical standards in a global world where values and cultures frequently clash. For example, the Western culture tends to favors liberalism yet the Middle-Eastern culture favors what the West would consider a Draconian sharia law to govern moral norms. Other critics (Gilligan, 1982) argue that Kohlberg's theory fails to take into account the "different voice" influenced by political, social, and economic contexts in addition to the ethics of caring, which may be exercised by both males and females. Rather than embracing theories of rights or justice, both Gilligan (1982) and McIntyre (1984) support an ethics of care that entertains the type of creativity required in international and culturally diverse affairs. However, French and Weis (2000) suggest an alternative position to those based on different cultural values, or the ethics of caring versus the ethics of justice debate, and that is one based on the agreement of a similar set of business values for all international commerce. Further, traditional value differences between negotiators should be superseded by the shared desire to resolve conflict. 


\section{INTERNATIONAL STRATEGIES}

Fisher and Bonn (2007) suggest that international strategies are a long-term orientation of how the organization will operate across borders. A critical issue is the difference in standards and values across the various countries. Organizations can pursue global, multinational or transnational strategies when operating in international markets. Those that pursue a multinational strategy emphasize the importance of local responsiveness and decentralize their strategic and operating decisions to the subsidiaries in each country. Those that pursue a transnational strategy, global and local perspectives complement and inform each other and the main challenge for the manager is to balance the two.

\section{HUMAN RIGHTS}

According to Sen $(2004$, p. 319) a "theory of human rights cannot be sensibly confined within the juridical model in which it is frequently incarcerated". In other words, human rights are concerned with ethical demands, calls for social justice, public awareness, advocacy, and political action in addition to legal norms and rules. Whilst some claim adding human rights to the already complex issues and divergent views on climate change is disadvantageous, this paper supports those who contend that the two are inextricably linked when viewed from the perspective of the most vulnerable nations to climate change (Kennedy, 2005).

The ethical branch of human rights claims by virtue of their humanity, all humans are born with a set of rights that imply obligations and duties for other people (Seymour \& Pincus, 2008). The legal branch maintains prescribed rights according to manmade law. The United Nations Office of the High Commissioner for Human Rights (OHCHR, 2009) declared the difficulties in qualifying climate change as a human rights issue due for several reasons. First, the complexity of relationships linking greenhouse gas emissions to particular nations makes it virtually impossible to compensate for human rights violations. Second, global warming is often one of several factors interacting to violate human rights. Third, adverse effects are often based on projections whereas human rights violations are normally assessed after the fact (Jeurissen \& Keijzers, 2004). Although Gugler and Shi (2009) debate the efficacy (or futility) of methods for addressing human rights and poor labor standards, Logsdon and Wood (2002) maintain that such matters can be championed through a business citizenship model which guides behavior as an organization matures from a domestic to a multinational entity. Hence, where public policy fails, the private sector can pursue through corporate adherence to internal standards. Sen (2004) claims human rights are a source for public and social recognition and help to base climate change by articulating values, ethics, and beliefs which can help others assist more vulnerable nations. Hence, climate change becomes a moral issue rather than a mere legal one.

\section{CONCLUSION}

According to Asgary and Mitschow (2002), any international code of business ethics is threatened by special interests in developed countries. For example, Western labor unions may seek to advance improved labor standards in emerging economies in an effort to increase productivity costs in those markets where cheaper labor costs had attracted outsourced activities. However, progressive nations still have better regulations for governing safety standards and human rights and a 1994 study of Fortune 500 industrial and 500 service corporations developed formal policies for dealing with perceived ethical situations as they occur. Najam (2005) argues that North-South (or developed and less developed nations) inequalities with climate change policies remain a fundamental hurdle caused by differences in framing the issues as a whole. Organizations such as The Caux Principles Roundtable and the World Bank encourage fairness and respect for others by promoting free trade, environmental and cultural integrity, and the prevention of foreign corrupt practices as defined by U.S. law.

The complexity and competitiveness of global markets mean that sustainability and pollution prevention do not always appear compatible with profitability and leaders are challenged to choose between the two. An unfettered and unregulated market does not readily embrace climate change and human rights initiatives since such activities may interfere with productivity and profit. Seeking global solutions based on sector or industry might contribute to a more collaborative effort to improve standards, although building trust is undoubtedly a long-term goal worthy of pursuit in itself. Indeed, by definition, the obsession with finding quick fixes, quick wins, and fast growth are counterproductive to finding a sustainable solution - even though they contribute to survival. 
On an international level, there is a need for an integrated approach towards bringing stability to highly influential oil-producing nations. This might help control the cost of oil which continues to be driven by a concentrated industry where few competitors, recognizing their own mutual interdependence, restrain rivalry to maintain high prices. On a national level, Mr. Obama has the opportunity to lead a transformational effort by transcending domestic interests for members of the broader global network, and to review long-term foreign policy that has been underpinned by the costly pursuit of an unsustainable resource in a region of intense conflict. Indeed, the true cost of oil needs to internalize the external costs associated with the numerous conflicts of attrition in the Middle-East region. Government needs to use its power to set prices, regulations, and standards to reshape the entire energy and supporting industries. Unfortunately, the system of government is so designed that such an arduous task might well find an incumbent politician voted out of office the following term.

As history has shown, neither government nor the private sector alone seems able to tackle climate change and human rights issues successfully. Perhaps part of the problem is caused by the polarized ideologies that are blinding policy makers and private sector business leaders to the opportunities to be gained by working collaboratively for an enduring solution. However, this means compromise and the average citizen will need to express a willingness to change consumer and voting habits if corporations are to follow suit. Clearly the current environment is one lacking in trust and it may take a bottom up approach from the consumer to help corporations recognize how a new industry could be created which would support a sustainable and compassionate future compatible with wealth generation and redistribution. With this in mind, government needs to work closely with virtuous business leaders for a broad solution to creating and redistributing wealth based on the virtues of rights, justice, and fairness for all. This may well involve grants and micro-loans for the development of grass-roots projects that support communities in an environmentally and ethically responsible manner. Such initiatives are already taking root in relatively small communities across the globe from wind turbines constructed from discarded bicycles in Africa, to recycled Coca Cola bottles used as lights bulbs in shanty town housing in China, to the communal compost in Key West, Florida.

\section{AUTHOR INFORMATION}

Val Candy is completing her doctoral studies in management and organization. She is published in the areas of organizational behavior, leadership, and strategy. Val consults on a range of government reform issues including healthcare management and waste diversion. She has worked extensively in leadership positions in the United Kingdom, as a policy development advisor for the Department of Education and Skills, and in the United States where she is developing a credentialing and accreditation process for a national not-for-profit. E-mail: vucandyms@gmail.com

\section{REFERENCES}

1. Aaronson, S. (2005). "Minding our own business": What the United States Government has done and can do to ensure that U.S. multinationals act responsibly in foreign markets. Journal of Business Ethics, 59: 175-198.

2. Andresen, A., \& Agrawla, S. (2002). Leaders, pushes, and laggards in the making of the climate regime. Global Environmental Change, 12, 41-51.

3. Asgary, N., \& Mitschow, M. (2002). Toward a model for international business ethics. Journal of Business Ethics, 36, 239-246.

4. Beerel, A. (2009). Leadership and change management. San Francisco, CA: Sage Publications.

5. Brown, M. E., \& Trevino, L. K. (2006). Socialize charismatic leadership, values congruence, and deviance in work groups. Journal of Applied Psychology, 91, 954-962.

6. Cosans, C. (2009). Does Milton Friedman support a vigorous business ethics? Journal of Business Ethics, 87,391-399.

7. Dalla Costa, J. (1998). The ethical imperative: Why moral leadership is good business. Toronto, Ontario, Canada: Harper Business.

8. $\quad$ Dean, J., \& Tsai, T. (2010, May 27). Suicides spark inquiries. The Wall Street Journal, pp. B1,B7.

9. Dobbin, M. (1998). The myth of the good corporate citizen: Democracy under the rule of big business. Toronto, Ontario, Canada: Stoddart. 
10. Donaldson, T. (1989). The ethics of international business. Oxford, England: Oxford University Press.

11. Dowling, J., Festing, M., \& Engle, A. (2009). International human resource management $\left(5^{\text {th }}\right.$ ed.). Mason, $\mathrm{OH}$ : Cengage.

12. Drucker, P. (2001). The essential Drucker. New York, NY: HarperCollins.

13. Falkenberg, A. (2004). When in Rome. Moral maturity and ethics for international economic organizations. Journal of Business Ethics, 54(1), 17-32.

14. Fisher, J., \& Bonn, I. (2007). International strategies and ethics. Management Decision, 45, 1560-1572.

15. Freeman, R. E. (1994). The politics of stakeholder theory: Some future directions. Business Ethics Quarterly, 4(4), 409-421.

16. French, W., \& Weis, A. (2000). An ethics of care or an ethics of justice. Journal of Business Ethics, 27,125-136.

17. Friedman, M. (1970, September 13). The social responsibility of business is to increase its profits. New York Times, pp. 32, 122-124.

18. Friedman, T. (2008). Hot, flat, and crowded. Why we need a green revolution - and how it can renew America. New York, NY: FSG Press.

19. Frost, M. (2003). Tragedy, ethics, and international relations. International Relations, 17, $477-495$.

20. Gaur, A. (2006). Changing demands of leadership: A survey of Indian leaders. IIMB Management Review, 2, 149- 158.

21. Gilligan, C. (1982). In a different voice: Psychological theory and women's development. Cambridge, MA: Harvard University Press.

22. Goodpaster, K. (1991). Business ethics and stakeholder analysis. Business Ethics Quarterly, 1(1), 53-73.

23. Gugler, P., \& Shi, J. (2009). Corporate social responsibility for developing country multinational corporations: Lost war in pertaining global competitiveness? Journal of Business Ethics, 87, 3-24.

24. Heath, J. (2006). Business ethics without stakeholders. Business Ethics Quarterly, 16(4), 533-557.

25. Hohne, N., \& Block, K. (2005). Calculating historical contributions to climate change. Climate Change, 71,(2), 141-173.

26. Hunt, S. D., \& Vasquez-Parraga, A. Z. (1993). Organizational consequences, marketing ethics, and salesforce supervision. Journal of Marketing Research, 30, 78-90.

27. Hyman, M. R. (1996). A critique and revision of the multidimensional ethics scale. Journal of Empirical Generalizations in Marketing Science, 1, 1-35.

28. Jeurissen, R., \& Keijzers, G. (2004). Future generations and business ethics. Business Ethics Quarterly, 14(1), 47-69.

29. Kennedy, D. (2005). Challenging expert rule: The politics of global governance. Sydney Law Review, 27, 515.

30. Koehn, D. (1998). Virtue ethics, the firm, and moral psychology. Business Ethics Quarterly, 8(3), 497-513.

31. Logsdon, J. M., \& Wood, D. (2002). Business citizenship: From domestic to global level of analysis. Business Ethics Quarterly, 12(2), 155-187.

32. MacIntyre, A. (1985). After virtue ( $2^{\text {nd }}$ ed.). London, England: Duckworth.

33. Moore, G. (2005). Corporate character: Modern virtue ethics and the virtuous corporation. Business Ethics Quarterly, 15(4), 659-685.

34. Moran, T. H. (2005). Monitoring compliance with international labor standards: How can the process by improved, and what are the implications for inserting labor standards into the WTO? Journal of Business Ethics, 59, 147-153.

35. Murphy, P. E. (1999). Character and virtue ethics in international marketing: An agenda for managers, researchers and educators. Journal of Business Ethics, 18(1), 107-125.

36. Nozick, R. (1974). Anarchy, state, and Utopia. New York, NY: Harper Basic Books.

37. O'Brien, K. L., \& Leichecko, R. M. (2003). Winners and losers in the context of global change. Annals of the Association of American Geographers, 93(1), 89-103.

38. Powell, S., \& Casselman, B. (2010, February 17). Defections shake up climate coalition. The Wall Street Journal, p. A1, A4.

39. Rawls, J. (1993). Political liberalism. New York, NY: Columbia University Press.

40. Rest, J. (1986). Moral development: Advances in research and theory. New York, NY: Praeger.

41. Rodrigues, C. (2009). International management ( $3^{\text {rd }}$ ed.). Los Angeles, CA: Sage. 
42. Rosenthal, E. (2011, December 9). Used batteries from U.S. expose Mexicans to risk. The New York Times, pp. A1, A12.

43. Schermerhorn, J. (1999). Terms of global business engagement in ethically challenging environments: Applications to Burma. Business Ethics Quarterly, 9(3), 485-505.

44. Schwartz, M. S. (2002). A code of ethics for corporate code of ethics. Journal of Business Ethics, 41, 2743.

45. Sen, A. (2004). Elements of a theory of human rights. Philosophy and Public Affairs, 32(4), $315-356$.

46. Seymour, D., \& Pincus, J. (2008). Human rights and economics: The conceptual basis for their complementarily. Development Policy Review, 26(4), 387-405.

47. Shanahan, K., \& Hyman, M. (2003). The development of a virtue ethics scale. Journal of Business Ethics, 42,197-208.

48. Shaw, W. H. (2009). Marxism, business ethics, and corporate social responsibility. Journal of Business Ethics, 84, 565-576.

49. Short, D. C., \& Callahan, J. L. (2005). "Would I work for a global corporation?” and other ethical questions for HRD. Human Resource Development International, 8(1), 121-125.

50. Steidlmeier, P. (1997). Business ethics and policy in China. Business Ethics Quarterly, 7(3), $131-144$.

51. Stieb, J. A. (2009). Assessing Freeman's stakeholder theory. Journal of Business Ethics, 87, 401-414.

52. Svensson, G., \& Wood, G. (2008). A model of business ethics. Journal of Business Ethics, 77, 303-322.

53. Trevino, L., \& Nelson, K. (2004). Managing business ethics ( ${ }^{\text {rd }}$ ed.). Hoboken, NJ: John Wiley.

54. United Nations Framework Convention on Climate Change. (2009). Copenhagen accord available at http://unfccc.int/files/meetings/cop_15/application/pdf/cop15_cph_auv.pdf

55. Vilanova, M., Lozano, J. M., \& Arenas, D. (2009). Exploring the nature of the relationship between CSR and competitiveness. Journal of Business Ethics, 87, 57-69.

56. Velasquez, M. G. (1996). Why ethics matters: A defense of ethics in business organizations. Business Ethics Quarterly, 6(2), 201-221.

57. Weaver, G. (2001). Ethics programs in global business: Culture's role in managing ethics. Journal of Business Ethics, 30, 3-15.

58. Weidgant, E. (2008). Darkening peaks: Glacier retreat, science, and society. University of California Press.

59. Windsor, D. (2004). The development of international business norms. Business Ethics Quarterly, 14(4), 729-754. 


\section{NOTES}

